\title{
Kullanıcı türevli içeriklerin satın alma davranışına etkisi üzerine bir araştırma ${ }^{1}$
}

\section{A study on the effect of user-generated content on purchase behaviour}

\begin{abstract}
${ }^{1} \mathrm{Bu}$ makale, birinci yazarın ERÜ SBE'nde ikinci yazar danışmanlığında yürütülen “İnternet Kullanıcılarının Ürettiği İçeriğin Tüketici Davranışına Etkisi Üzerine Bir Araştırma" isimli yüksek lisans tezinden üretilmiştir.
\end{abstract}

2 Erciyes Üniversitesi, Kayseri, Türkiye,
tugbabamyacioglu@gmail.com

ORCID: 0000-0002-0366-6604

${ }^{3}$ Doç. Dr., Erciyes Üniversitesi, Kayseri, Türkiye, etanyeri@erciyes.edu.tr

ORCID: 0000-0003-2731-5996

\section{Sorumlu Yazar/Corresponding Author:}

Tuğba Bamyacioğlu,

Erciyes Üniversitesi, Kayseri, Türkiye, tugbabamyacioglu@gmail.com

\section{Başvuru/Submitted: 12/07/2021}

1. Revizyon/1. Revised: 18/08/2021

2. Revizyon/ 2. Revised: 23/08/2021

Kabul/Accepted: 24/08/2021

Yayın/Online Published: 25/08/2021

Atıf/Citation: Bamyacıoğlu, T., \& Tanyeri Mazıcı, E., Kullanıcı türevli içeriklerin satın alma davranışına etkisi üzerine bir araştırma, tujom (2021) 6 (2):143-159, doi: https://doi.org/10.30685/tujom.v6i2.120

\author{
Tuğba Bamyacioğlu² \\ Emel Tanyeri Mazıc1 ${ }^{3}$ \\ Öz
}

Teknolojik alanda yaşanan gelişmeler, tüketicilerin dijital ortamda içerik üreterek güçlenmelerini sağlamaktadır. Özellikle profesyonel olmayan, satış veya reklam kaygısı gütmeyen tüketici yorumları, kullanıcı içerikleri olarak ifade edilmektedir. Bu süreçte hem dijital alanı kullanım sıklıkları hem de içerik üretimine sağladıkları katkı nedeniyle genç yaş grubunda yer alan tüketiciler önem taşımaktadır. Bu çalışmada genç tüketiciler arasında kullanıcı içeriklerinin tüketici davranışına etkisini incelemek amaciyla nicel yöntem tercih edilmiş, 24-27 Nisan 2018 tarihlerinde Erciyes Üniversitesinden 463 iletişim fakültesi öğrencisine yüz yüze anket çalışması yapılmıştır. Bulgulara göre genç tüketicilerin kullanıcı içeriklerinden en çok seyahat planlaması yaparken yararlandıkları sonucuna varılmıştır. Ayrıca katılımcılar kullanıcı içeriklerinden sırasıyla; teknolojik ürün satın alırken, sinema veya film seçerken, restoran ve kitap tercihi yaparken yararlanmaktadırlar. Genç tüketiciler hem negatif hem pozitif tüketici içeriklerinden etkilenmekle beraber daha çok negatif kullanıcı içeriklerini dikkate almaktadırlar. Katılımcıların internette geçirdikleri süre arttıkça kullanıcı içeriklerinden etkilenme düzeyleri artmakta ancak içerik üretme eğilimleri artış göstermemektedir. Katılımcıların kurumsal içeriklere duydukları güven ile kullanıcı içeriklerine duydukları güven eşittir ve en çok olumsuz tüketim deneyimi yaşadıklarında içerik üretmeye eğilimlidirler.

Anahtar Kelimeler: Kullanıcı Türevli İçerik, Tüketici Yorumları, Tüketici Davranışı, Tüketici Deneyimi Etkisi

Jel Kodları: M31, M37

\begin{abstract}
Developments in the technological field have enabled consumers to gain an important place in creating content in the digital environment. In particular, non-professional consumer comments that do not have any sales or advertising concerns are expressed as user content. In this process, young consumers are essential because of their frequency of using the digital domain and their contribution to content production. In this study, a survey has been conducted to the students of Erciyes University by choosing the quantitative research method to examine the effect of user content on consumer behaviour among young consumers. According to the findings obtained as an outcome of the research, it has been concluded that young consumers mainly benefit from user content while planning their travels. In addition to travelling planning, the participants use it while purchasing technological products, choosing a movie or cinema, choosing a restaurant, and choosing a book. Although young consumers are affected by negative and positive consumer content, they mainly consider harmful user content. As the time the participants spend on the internet increases, their level of exposure to user content increases, whereas the time they spend on the internet increases, their tendency to produce content does not increase. Participants' trust incorporate content is equal to their trust in user content, and they tend to produce content most when they experience harmful consumption.
\end{abstract}

Keywords: User Generated Content, Consumer's Comments, Consumer Behavior, Consumer Experience Impact

Jel Codes: M31, M37 


\section{Extended Abstract}

\section{A study on the effect of user-generated content on purchase behaviour}

\section{Literature}

While UGC (User Generated Content) expresses the concept of content produced by users, MGC (Marketing Generated Content) expresses the concept of content produced by marketers (Yong Goh, Heng, and Lin, 2013, p. 105). User-generated content; is helpful and sometimes entertaining data voluntarily provided by people (Handley and Chapmen, 2012, p. 143) produced by visiting people or customers other than professional writers, content creators, or production companies (Krumm, Davies, and Narayanaswami, 2008, p. 10). User-generated content production takes place using tools that allow the public to express a desire or desire creatively (Hermida and Thurman, 2007, p. 24). User-generated content must meet the following three conditions, s. The obligation to be published outside of creative effort and professional routines (Vickery and Vincet, 2007, p. 8). Research on consumers' orientation to word-of-mouth marketing in the digital environment, economic incentives, social interaction, responsibility towards other consumers, the need to feel valued (Toros, 2016, p. 163). UGC provides direct or indirect advice for product purchases. Positive UGC increases the expected quality of the product, while negative UGC decreases the expected quality. Negative UGC may contain slurs, rumours, and private complaints, harming product sales, while positive UGC improves consumers' attitudes towards the product (Liu, 2006, p. 76).

\section{Research subject}

This research focuses on the effect of user-generated content on consumer behaviour, which is thought to play an essential role in the consumer's purchasing decision and their tendencies to produce content.

\section{Research purpose and importance}

Consumer content is valuable because it is independent of sales and profit motives. It is a clue for consumers in the crowd of advertising content. This research aims to explore the effects of user content on young people and their tendencies to produce content.

\section{Contribution of the article to the literature}

While similar studies are generally framed by the effect of social media on consumer behaviour in the literature, this study has compiled consumer content and effects both in and outside of social media. This contributes to its holistic aspect.

\section{Design and method}

\section{Research type}

This is an applied study with a quantitative method. It also has a causal and descriptive design.

\section{Research questions}

- Are variables such as gender and time spent online related to influence from consumer content?

- What kinds of experiences are affected by students' tendencies to produce content as consumers?

- What types of consumer content are they most attracted to?

- Do students rely more on corporate or consumer voluntary content?

\section{Data collection method}

The questionnaire method is used in this study. Questions about the usefulness of user content and its effect on purchase intention Mikalef, Giannakos and Pateli (2013, p. 33-34) and To, Liao and Lin (2007, p. 782) questions about user content before and after purchase İşlek (2012, p. 164-168) questions about the tourism and travel effects of user content were adapted from the studies of Cox, Burgess, Sellitto, Buultjens (2009, p. 760) according to the purpose and content of the researcher. The survey consists of two main parts as pre-purchase and post-purchase. It also includes sections asking about the duration of internet usage, the devices on which the internet is used, the preferred social network types, and finally, it requests age and gender information. There are 20 statements in the pre-purchase section and five statements in the post-purchase section. 5 Likert type scales were used to measure the agreement with these statements. The central mass of the research is university-age youth, and the sample is Erciyes University students. Data were collected from 463 people in 4 days.

\section{Quantitative/qualitative analysis}

In this study, which was approached with the quantitative method, parametric tests were applied. In addition, frequency analyses were conducted in the study to find answers to the research questions and reliability analyses. 


\section{Research model}

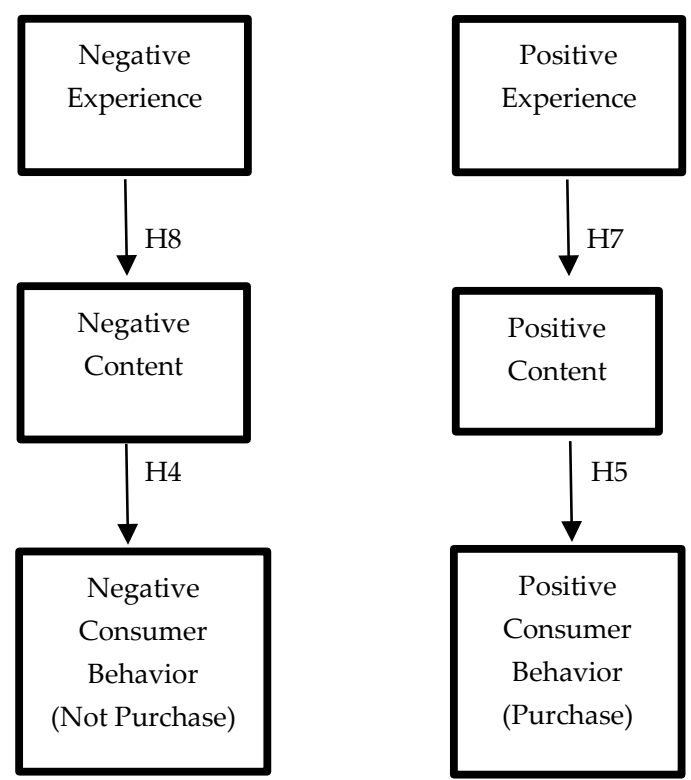

Figure 1: Research Model

\section{Research hypotheses}

$\mathrm{H}_{1}$. The level of influence from user content may differ according to gender.

$\mathrm{H}_{2}$. Depending on the time spent on the internet, the level of influence of the participants by the user content may differ.

$\mathrm{H}_{3}$. The level of a tendency to produce content may differ according to the time spent on the internet

$\mathrm{H}_{4}$. There is a positive relationship between harmful user content and negative consumer behaviour.

$\mathrm{H}_{5}$. There is a positive relationship between positive user content and positive consumer behaviour.

H6. Trust in user-generated content is higher than trust incorporate content.

H7. There is a positive relationship between the positivity of the consumption experience and the tendency to produce comments/opinions.

$\mathrm{H}_{8}$. There is a positive relationship between the negativity of the consumption experience and the tendency to produce comments/opinions.

\section{Finding and discussion}

\section{Findings as a result of analysis}

According to the findings, it was concluded that young consumers primarily benefit from user content while planning travel. In addition, the participants, respectively, from the user content, benefit from purchasing technological products, choosing a cinema or a movie, choosing a restaurant, and choosing a book. Young consumers are affected by negative and positive consumer content, but they mainly consider harmful user content. As the time spent by the participants on the internet increases, the level of being affected by user content also increases, but the time they spend on the internet does not increase their tendency to produce content. Participants' trust incorporate content is equal to their trust in user content, and they tend to produce content most when they experience harmful consumption. The gender variable does not significantly affect producing or being affected by content related to consumer experiences. 


\section{Hypothesis test results}

Table 1: Hypothesis and hypothesis test results

\begin{tabular}{|c|c|}
\hline $\begin{array}{l}\text { H. Depending on gender, the level of influence from user content may differ. } \\
\text { İndependent sample t test } p: 0,358 \text { - Pearson chi square test } p: 0,306\end{array}$ & Reject \\
\hline $\begin{array}{l}\mathrm{H}_{2} \text {. Depending on the time spent on the internet, the level of influence of the participants by the user content may } \\
\text { differ. } \\
\text { Pearson chi square p: 0,001 - One way anova p: 0,001 }\end{array}$ & Accept \\
\hline $\begin{array}{l}\text { H3. The level of a tendency to produce content may differ according to the time spent on the internet. } \\
\text { Pearson chi square p: } 0,448 \text { - One way anova p: } 0,302\end{array}$ & Reject \\
\hline $\begin{array}{l}\mathrm{H}_{4} \text {. There is a positive relationship between harmful user content and negative consumer behaviour. } \\
\text { Pearson chi square p: } 0,001 \text { - Pearson correlation p: } 0,402\end{array}$ & Accept \\
\hline $\begin{array}{l}\text { H5. There is a positive relationship between positive user content and positive consumer behaviour. } \\
\text { Pearson chi square p: } 0,001 \text { - Pearson correlation p: 0,439 }\end{array}$ & Accept \\
\hline $\begin{array}{l}\text { H6. Trust in user-generated content is higher than trust incorporate content. } \\
\text { Paired sample } t \text { test p: 0,508 }\end{array}$ & Reject \\
\hline $\begin{array}{l}\text { H7. There is a positive relationship between the positivity of the consumption experience and the tendency to } \\
\text { produce comments/opinions. } \\
\text { Pearson chi square p: } 0,001 \text { - Pearson correlation p: } 0,332\end{array}$ & Accept \\
\hline $\begin{array}{l}\text { H8. There is a positive relationship between the negativity of the consumption experience and the tendency to } \\
\text { produce comments/opinions. } \\
\text { Pearson chi square p: } 0,001 \text { - Pearson correlation p: } 0,278\end{array}$ & Accept \\
\hline
\end{tabular}

\section{Discussing the findings with the literature}

According to research, consumers; it is claimed that they rely more on informal and personal communication sources in their purchasing decisions compared to sources such as official, corporate, and advertising campaigns (Bansal and Voyer, 2000), and they prefer peer or editorial suggestions over sponsored advertisements (Smith, Menon, and Sivakumar, 2005, s. 32). However, the findings of this study do not support the knowledge that voluntarily produced content in the literature is more reliable than professional advertising content. It is anticipated that this finding will change with more sophisticated data collection tools.

\section{Conclusion, recommendation, and limitations}

\section{Results of the article}

The research has shown that the internet is mainly used via smartphones and the majority of those spend more than 5 hours a day on the internet. In the examinations made for the participants to produce content related to the product they purchased, it was revealed that there is a tendency to produce more content if the product or service purchased is not satisfied. Participants are affected by both positive and negative user comments, but they are mostly affected by negative comments. When consumers are affected by user content after purchasing, and their tendencies to produce content are examined, it is argued that the participants produce content when they are not satisfied the most. Based on this information, it can be said that users tend to produce harmful content when they are more dissatisfied with their consumption experience.

\section{Suggestions based on results}

User content is valuable in that it is entirely independent of professional institutions and any profit motive. User content can influence purchasing decisions through both informative and persuasive interactions. All structures discussed in the digital environment, such as tangible product vendors, tourism companies, restaurants, and cultural and artistic works, should aim at quality and service that will enable them to produce positive content for their consumers.

\section{Limitations of the article}

This study is limited to university students only. More detailed results can be obtained in sample groups with rich variables. 


\section{Giriș}

Piyasada arzlar talepleri aştığından beri artan rekabet, pazarlama ve reklam çabalarını arttırmış, teknolojinin de bu gelişmelere eklenmesiyle günümüz insanının çevresini reklam ve reklam amacı taşıyan yapılandıılmış içerikler sarmıştır. Kullanıcı içerikleri profesyonel firmalardan ve kar amacından tamamen bağımsız olması yönüyle değerlidir. Dijital dünyada reklam ve reklam amacı güden içerik yığını altında sislenen algılar gerçek kullanıcı/tüketici içeriklerine daha duyarlı hale gelmektedir. Kullanıc içerikleri, hem bilgilendirici hem de ikna edici etkileşimler yoluyla satın alma kararlarını etkileyebilmektedir. Gerçek kullanıcı görüşleri şirketlerin imaj veya satış kaygısından bağımsızdır. Bu bağımsız niteliği sayesinde pek çok alandaki tüketici tercihini etkileyebilirler. Kullanıcılar, sosyal medya sitelerinde ürettikleri içeriklerin yanı sıra sosyal medya sitelerinin dışındaki platformlarda da içerik üretmektedirler. Tüketicilerin ürün incelemelerini ve tüketim deneyimlerini paylaştığı çok sayıda web sitesi ve platform mevcuttur. Seyahat tüketicilerinin otel ve destinasyon değerlendirmelerinden, restoran ve yeme içme deneyimlerine, kitap, film ve müzikten kültür sanat aktivitelerine kadar çok çeşitli alanda kullanıcı görüşleri/içerikleri önemli bir yere sahiptir. Tüketicilerin ürün incelemelerini içeren paylaşımlar, karar vermede etkili olabilecek tavsiyelerin yanı sıra ürünlerin bilinmezliğine karşı da güven yaratmaktadır.

İnternet teknolojilerinin sunduğu çift yönlü ve anlık iletişim, aktif kullanıcıların olduğu çevrimiçi bir dünya yaratmıştır. İnternet kullanıcılarının içerik üretebilmesi ise; üretim araçlarının demokratikleşmesinden kaynaklanma, basit ve ucuz yazılım ve hizmetlerin herkesin kullanımına sunulması internette yayıncılığı kolaylaştırarak, pasif tüketicileri aktif üreticiler haline getirmektedir (Anderson, 2008, s. 72). Web 2.0, bilgiyi yeni yollarla entegre becerisine sahip kullanıciların duydukları katkı sağlama arzusu ve angaje olma ihtiyacını içeren bir dizi prensiptir ve kullanıcı tarafından üretilen içerik ile ilişkili bir kavramdır (O'Reilly, 2012). UGC (User Generated Content), kullanıcıların ürettiği içerik kavramını ifade ederken, MGC (Marketing Generated Content), pazarlamacıların ürettiği içerik kavramını ifade etmektedir (Yong Goh, Heng, ve Lin, 2013, s. 105). Kullanıcı tarafından üretilen içerik; profesyonel yazarların, içerik yaratıcılarının ya da prodüksiyon şirketlerinin haricinde ziyaretçi insanlar veya müşteriler tarafından üretilen, (Handley ve Chapmen, 2012, s. 143) gönüllü olarak sağlanan kullanışlı ve bazen de eğlenceli (Krumm, Davies, ve Narayanaswami, 2008, s. 10) verilerdir. Kullanıcı kaynaklı içerik üretimi, halkın bir arzu veya isteğini, yaratıcı bir biçimde ifade etmesine izin veren araçlardan faydalanmasıyla gerçekleşmektedir (Hermida ve Thurman, 2007, s. 24). Kullanıcı kaynaklı içeriğin şu üç şartı taşıması gerekir ki bunlar; yayınlanma zorunluluğu, yaratıcı çaba ve profesyonel rutinlerin dışında olmaktır (Vickery ve Vincet, 2007, s. 8). Türkçe literatürde KÜİ (Kullanıcıların Ürettiği İçerik) olarak görmek mümkün olsa da daha çok UGC (User Generated Content) veya CGC (Consumer Generated Content) olarak karşımıza çıkmaktadır. Pazarlama terminolojisinde UGC, tüketiciden tüketiciye e-pazarlamanın etkili bir formudur ve bu terim, bir ürün veya hizmet hakkında fikir sahibi olan birinin görüşlerini, inançlarını ve deneyimlerini diğer insanlarla paylaşması nedeniyle, elektronik ağızdan ağıza iletişime eşit görülmektedir (Ahuja, Michels, Walker ve Weissbuch 2007, s. 151). Online ürün değerlendirmeleri, kullanıcı görüşleri, müşteri değerlendirmeleri gibi kavramlar birer kullanıcı içeriği oldukları için yapı ve işlev bakımından e-WOM'ların kullanıcı içeriği olarak ifade edilebileceğini ileri süren çalışmalara rağmen (Chatterjee 2001; Dellarocas, Zhang, ve Awad, 2007; Liu, 2006) e-WOM ve UGC'nin birbirlerinin yerine kullanılamayacağını ve farklarını ortaya koyan çalışmalar da mevcuttur (Thi, Shurong, Distric, 2020, s. 45). Yayınlanma zorunluluğu, çevrimiçi ulaşılabilirlik, kaynak-alıcı belirsizliği ve bilgi dağıtımı gibi özellikler ikisinde de ortak iken, ticari etkilerden bağımsız olma, yaratıcı çaba gerektirmeme nitelikleri ile e-WOM UGC'den ayrılmaktadır (Thi vd. 2020, s. 45). UGC ve e-WOM arasındaki bir diğer ayrım ise UGC'de ileti içerikleri kullanıcı tarafından üretilirken e-WOM sadece iletilip, transfer edilebilmektedir (Smith, Fischer, Yongjian, 2012'den akt. Thi vd., 2020, s. 45).

Bireylerin satın alma kararlarında resmi, kurumsal ve reklam kampanyaları gibi kaynaklara nazaran, gayri resmi ve kişisel iletişim kaynaklarına daha fazla güvenmekte olduğu (Bansal ve Voyer, 2000) ve akran veya editör önerilerini, sponsorlu reklamlara açık ara tercih ettikleri ileri sürülmektedir (Smith, Menon, ve Sivakumar, 2005, s. 32). UGC ürün satın alımı için doğrudan veya dolaylı tavsiyeler vermektedir. Pozitif UGC üründen beklenen kaliteyi arttırırken, negatif UGC beklenen kaliteyi azaltmaktadır. Negatif UGC aşağılama, söylenti ve özel şikayetler içerebilir ve bunlar ürün satışına zarar verebilirken, pozitif UGC tüketicilerin ürüne yönelik tutumlarını iyileştirmektedir (Liu, 2006, s. 76). 
Reklam içeriklerinin bolluğu karşısında bunalan modern insanın kullanıcı içeriklerinden etkilenme eğilimi, tüketici tutumunu anlamak açısından önemlidir. UGC'nin yaygınlaşması tüketiciler, medya tedarikçileri ve pazarlama profesyonellerinde güçlü bir etki yaratırken, bu medya içeriğinin hem kısa hem de uzun vadeli etkilerini anlama ihtiyacı araştırmaları gerekli kılmaktadır (Daugherty, Eastin, ve Bright, 2008, s. 16). Bu çalışma sadece sosyal medya açısından kullanıcı içeriklerini ele alan çalışmalardan farklı olarak bütün çevrimiçi ortamlardaki kullanıcı içeriklerinin tüketici tutumuna etkisini ele almaktadır. Örneğin Ali Express veya Trenyol'daki ürün değerlendirmeleri de birer kullanıcı içeriğidir ama bu siteler sosyal medya değil alışveriş siteleridir. E- Ticaret hacim ve alışkanlığının artmasıyla kullanıcı/tüketici yorumları son derece önemli bir hale gelmiştir.

\section{Kullanıcı kaynaklı içeriklerin tüketici üzerindeki etki alanları}

Genel olarak, UGC, satın alma davranışında MGC'den (Marketing Generated Content) daha etkili bir rol oynamaktadır (Yong Goh vd., 2013). Tüketicinin ürünü satın alma aşamasında, işletmeler tarafından hazırlanan içerik aktif rol oynarken, tüketici yani kullanıcı tarafından geliştirilen içerik, tüketicinin ürün veya hizmet deneyimine bağlı olarak tüketici tarafından yaratılmaktadır (Karkar, 2016, s. 335). Satın alma sürecinde yönlendirilmemiş içerikler, yönlendirici olanlardan ve tüketiciye yönelik ikna edici iletişimden daha etkilidir. UGC hem bilgilendirici hem de ikna edici roller oynamaktadır. Ayrıca çevrimiçi topluluk üyelerinin, diğer üyelerle benzer fikir ve kararları daha fazla benimseme eğilimi, kullanıcı tarafından üretilen içeriğin etkisini arttırmaktadır (Bagozzi ve Dholakia, 2002, s. 18).

Kullanıcılar tarafından üretilen içeriklerin tüketicilerin davranışları üzerinde etkisi olduğu düşünülmektedir. Örneğin Epinions.com, BizRate.com, Ecomplaints.com, Planetfeedback.com gibi siteler, tüketicilerin ürün incelemelerini ve tüketim deneyimlerini paylaşttğ̆ yabancı sitelerken (Smith vd. 2005, s. 16) Türkiye'nin iki e-ticaret devi Trendyol ve Hepsiburada' da kullanıcı yorumlarının sayısı bir ürün için dahi binlerce kullanıcı yorumunu bulmaktadır. Son zamanlarda e-ticaret siteleri arasında gittikçe yaygınlaşan fotoğraflı yorum yapabilme imkânı, stüdyo ortamında fotoğraflanmış yanıltıcı olabilecek ürün temsillerine karşı tüketicileri gerçeğe daha da yaklaştırmaktadır. Akran önerilerinin sanal marketlerdeki seçimler üzerinde etkisine yönelik bir araştırma, kullanıcı içeriklerinin çevrimiçi araştırma sırasında, verilen emeği azaltmak için iyi bir araç olarak görüldüğünü ileri sürmekte ve tüketicilerin akran önerilerini, sponsorlu reklamlara açıcça tercih ettiğini ortaya koymaktadır (Smith vd., 2005, s. 32).

\section{Turizm ve seyahat}

İnternet, seyahat planlama sürecinde şüphesiz çok önemli bir role sahiptir. İnternetin sunduğu UGC, destinasyon, turizm ve seyahat tüketicilerinin araştırma ve karar aşamasında başvurulan önemli bir kaynak haline gelmiştir. Kullanıcı deneyimini, seyahat konusunda spesifikleştiren siteler mevcuttur. Tripadvisior, Hotels.com, Air bnb kullanıcılarına rezervasyon imkânı vermenin yanı sıra yorum ve puanlama yapabilmesini ve bunlardan yararlanmasını sağlamaktadır. TripAdvisor; dünya çapında beş milyondan fazla kayıtlı üyeye ve 10 milyondan fazla kullanıcıya sahiptir. Bir milyonun üzerinde otel ve cazibe merkezi hakkında inceleme ve görüş üretmiştir (TripAdvisor.com, 2018). O'Connor'a göre; TripAdvisor'ın bir parça sosyal medya, bir parça sanal topluluk ve aynı zamanda blog özellikleri içermesi nedeniyle kategorize bir tanımı zordur. Bununla birlikte, birincil işlevi kullanıcı tarafından üretilen içeriğin toplanması ve yaygınlaştırılması olmuştur. Bu içerikler; spesifik olarak seyahat alanında üretilen yorum, derecelendirme, fotoğraflardan oluşmaktadır. TripAdvisor, uyuşmazlık içeren sahte incelemeleri posta yoluyla uyararak güvenilir olmayan içeriği tolere etmeyen bir duruş sergilemektedir. Sistemi manipüle etmeye çalışan otellere sahte olduklarını belirten bir uyarı yorumu yayınlamakta ve sıralama konusunda cezalandırmaktadır. Yani Web 2.0 sitelerini simgeleyen "kalabalığın gücü" burada da geçerliliğini korumakta (O'Connor, 2008, s. 55) kendi kendini denetleyen bir güvenilirlik yaratmaktadır. Booking ise şu anda yurtiçinde kullanımı kapalı olsa da yurtdışı tatilleri için rezervasyon, puanlama ve UGC değerlendirmeleri sunarak rezervasyonuna sadık üyelerine genius unvanı vererek indirim sağlamaktadır. Tüketiciler tarafından yapılan seyahat yorumları, seyahat ile ilişkili kararlarda kullanılmaktadır ve sonuçlar göstermektedir ki kullanıcı içeriklerinden çoğunlukla konaklama kararı vermek ve seyahat rotası planlamak için yararlanılmaktadır (Gretzel, 2006, s. 35). Bu konuda bir araştırma, çoğu tüketici geniş bir yelpazede sunulan bilgileri dikkate alarak karar verdiği için, UGC sitelerinin henüz tam olarak güvenilir görülmediğini, gezginlerin bilgi arayışının tek değil ek bilgi kaynağı olduğu ileri sürmektedir (Burgess, Sellito, Cox ve Buultjens, 2009, s. 762). Ancak yine de 
UGC içeren siteler, gezginlerin planlama davranışı üzerinde gerçekten de bilgi sağlayıcı bir rol üstlendiği için ağırlama ve turizm organizasyonları bunu göz ardı etmemelidir (Burgess vd. 2009, s. 762). Kullanıcı deneyimini, seyahat konusunda spesifikleştiren bloglar da mevcuttur. Bireyler seyahat ettikleri yerlerden, konaklama türlerine, ulaşım tercihlerinden, seyahat zamanı seçimine kadar her türlü deneyimi gönüllü paylaşmaktadırlar. Bu konuda bahsedilmesi gerekenlerden en önemlisi seyahat deneyim ve tüyolarını özgün bir içerik haline getirerek sunan bizevdekoyuz.com'dur. 2017 ve 2018'de en iyi seyahat bloğu ve $2019^{\prime}$ da en iyi seyahat içerikli Youtube kanalı olarak, kullanıcı içeriğinin seyahat konusundaki başarılı bir örneğidir (bizevdeyokuz.com, 2021). Bu tür blogların, içerik yaratıcısına sponsorlu seyahat veya para gibi kaynaklar sağlayarak kazanç kapsına dönüşmesi, kullanıcı içeriklerinin ekonomik boyutuna işaret etmektedir.

\section{Restoran deneyimleri}

UGC'nin, müşterilerin kararları üzerindeki etkisi özellikle misafirperverlik endüstrisinde önemli bir yere sahiptir. Bu nedenle UGC restoran ve yeme içme deneyimleri üzerinde oldukça etkilidir. Müşteriler, deneyimlerinin farklı yönlerine ilişkin iyi veya kötü yorumlar yayınlamaktadır. İyi bir deneyime sahip bir müşteri tekrar ziyaret etme ve arkadaşlarına tavsiye etme eğilimindeyken, deneyim kötüyse bunun tam tersi söz konusudur (Tiago, Amaral ve Tiago, 2015, s. 162). Bu konuda günümüzün en popüler örnekleri olarak Foursquare ve Swarm verilebilir. Restoran müşterileri e-WOM'u ifade ettiklerinde, deneyimsiz müşterilere somut faktörler hakkındaki bilgilerini geliştirme fırsatı sağlamış olmaktadırlar. Namkung ve Jang; yemek sunumunun ve tadının, müşteri memnuniyeti ve davranışsal niyetlerle önemli ölçüde ilişkili olduğunu ortaya koymuştur (2007, s. 387). Bu duruma göre, işlerini arttırmak ve büyümek için UGC'nin gücünden yararlanmayı düşünen restoran yöneticileri kalitesini iyileştirerek pozitif içerik yaratabilmesi için müşteriye kaynak sağlamalıdırlar.

\section{Kültür ve sanat deneyimleri}

\section{Film}

Film tavsiye sistemlerinde; bir kişi benzer zevklere sahip olan bir gruba katıldığında, o topluluğun geçmiş zevklerine dayalı tavsiyeler alabilmektedir. Bu tür bilgiler yeterli olduğunda filmler için satın alma veya izleme kararı alınabilmektedir (Dhar ve Chang, 2009, s. 301). Film denildiği zaman akla ilk gelen, filmler hakkında eleştiriler yazılan ve notlar verilen aynı zamanda da sinema dünyası ve oyuncularla ilgili bilgiler içeren İmdb adlı internet sitesidir. Türkçesi; 'internet film veri tabanı' olan bu site, yeryüzündeki tüm ülkelerin ve tüm dönemlerin sinema ve televizyon filmleri, film yıldızları ve dizileri hakkında bilgiler barındıran çevrimiçi bir veri tabanıdır. Web sitelerinin web trafikleriyle ilgili bilgi veren bir site olan Alexa'nın TOP 50 listesinde yer almış olan İmdb'nin 70 milyon kayıtlı kullanıcısı bulunmaktadır. Ücretli veya ücretsiz üyelik sistemiyle kaydolma seçenekleri sunan İmdb, kullanıcıların katkılarıyla büyümektedir. Film hakkında yapılan her bir yorumun altında "yorum size yardımcı oldu mu?" diye sorulmaktadır. Evet ve hayır seçenekleriyle cevaplanan bu geri bildirim sistemi, kullanıcının üretmiş olduğu içerik üzerinde diğer kullanıcıların denetimini göstermektedir (İmdb.com, 2021).

\section{Tiyatro}

Bu noktada tiyatro, sergi, opera ve dans gibi kültür sanat aktiviteleri için geliştirilmiş mobil uygulamalardan da bahsedilebilir. Bu uygulamalarda da kullanıcıların gösteri ve sergiler için yaptıkları yorumlar ve puanlar bulunmaktadır. Bu konuda en profesyonel yönetilen web sitesi tiyatrolar.com örnek verilebilir. Yıldız vererek yapılan değerlendirmeler burada 10 üzerinden alkış vererek yapılmaktadır. Bu platformda, tiyatro izleyicileri oyunlarla ilgili önemli yorumlar yazmaktadır (tiyatrolar.com, 2021).

\section{Kitap}

Okuyucunun kitap seçme sürecinde yoğun zaman ve çaba harcamasının önüne geçen kitap tavsiye sistemlerinin başında "goodreads" örnek verilebilir. Goodreads, arkadaşlarımızın ne okuduğunu görebileceğimiz, inceleme yazıları yazılabilen ve bu incelemelere yorum yapılabilen bir sosyal ağdır. Aralık 2006'da yazılım mühendisi ve girişimci Otis Chandler tarafından kurulan özel bir sosyal kataloglama uygulamasıdır. Üyeler, aynı zamanda kendi kitap tavsiye ve tartışma gruplarını da oluşturabilmektedirler. Chandler; "arkadaşımın kitap rafinı tararken, aklıma geldi: hangi kitapları okuyacağıma karar verirken, rastgele bir kişi veya en çok satanlar listesinden ziyade bir arkadaşımın önerisini 
tercih ederim. (goodreads.com, 2021). Kullanıcı tavsiyelerinin tercihlerimize yön verdiği söylenebilirken bu tavsiyelerin yerinde olup olmadığı ayrı bir araştırma konusudur. Akran önerileriyle gelen kullanıcı içerikleri, tercih yaparken bize zaman kazandırması yönüyle aslında gönüllü olarak bize sunulmuş kısa yollardır.

\section{Müzik}

Müzikler ve şarkılar ile ilgili görüşlerini içerik olarak üreten ile, görüşleri alan kişinin zevkleri farklılık gösterebileceğinden müziği kelimeler ile anlatmak kitap ve filme göre daha zordur. Kullanımı kolay olan ve son derece kapsamlı müzik listelerine ücretsiz erişebilme imkânı sunan müzik paylaşım platformlarından önemli biri SoundCloud'dur. Bu uygulama; Web 2.0 üzerinden müzik ve ses dosyalarını ücretsiz olarak dinlemeye, indirmeye ya da yüklemeye izin veren Berlin merkezli çevrimiçi web uygulamasıdır. Ünlü sanatçıların parçalarının yanı sıra DJ'lerin kayıtları da yer almaktadır. Ayrıca kullanıcıların oluşturduğu 'Sunday Musics and hot Caffe...' gibi başlıkları olan çok sayıda çalma listesi mevcuttur. Bu uygulamanın çarpıcı yanı, çalan parçanın herhangi bir dakikasının üzerine tıklayarak o bölüm ile ilgili yorum yapılabilmesidir. Örneğin 2.14'e tıklayarak buradaki solo gitar hakkında yorum yapılabilmektedir. Bir başka ücretli müzik dinleme programı ise Spotify'dır. Spotify'da kullanıcılar birbirlerinin çalma listelerini dinleyebilmekte, listelerin yanında yazan dinlenme rakamları ise kullanıcıları daha çok tercih edilen müziğe doğru yaklaştırabilmekte, kullanıcılar birbirlerinin müzik tüketimlerini etkileyebilmektedir. Çünkü topluluk üyeleri, diğer üyelere benzer fikir ve kararları daha fazla benimseme eğilimindedirler ve böylece kullanıcı tarafından üretilen içeriğin etkisi artmaktadır (Bagozzi ve Dholakia, 2002, s. 18).

\section{Kullanıcı türevli içeriklerin tüketici tutumuna etkisi}

Tüketicilerin dijital ortamda ağızdan ağıza pazarlamaya yönelmeleri konusunda yapılan araştırmalar, sosyal etkileşim, diğer tüketicilere karşı duyulan sorumluluk, kendini değerli hissetme ihtiyacı gibi motivasyonların etkili olduğunu ortaya koymaktadır (Toros, 2016, s. 163). Ayrıca başkaları için endişe etmek (Engel'den akt. Hennig-Thurau, Gwinner, Walsh ve Gremler vd. 2004, s. 42) olumlu duygular1 ifade etme dürtüsü (Dichter'den akt. Hennig-Thurau vd., 2004, s. 44) ve kurumlara yardım etme hissi (Jeong ve Jang, 2011, s. 358-359) gibi dürtüler de UGC üretmenin motivasyonlarıdır. Daha derin motivasyonların neler olabileceğine bakıldığında; tutum teorisindeki etki mekanizmasının UGC üzerinde de etkili olduğu görülmektedir. Katz'ın ifade ettiğine göre tutum kavramı; uyum sağlama, ego savunması, değer ifadesi ve bilgi işlevleri ile anlaşılabilmektedir (Katz, 1960, s. 163). Daugherty vd.'nin keşifsel araştırmasıyla tutum teorisi UGC özelinde yeniden çerçevelendirilmiş ve UGC'nin işlevleri tutum teorisine dayanarak şöyle açılanmıştır; (2008, s. 17-18)

- Faydacı işlev, kişisel çıkarlara dayalı tutumları ifade etmekte, insanların ödül kazanmaya ve çevrelerinden cezalandırılmamaya motive olduklarını ileri sürmektedir. UGC açısından, bu motivasyonla içerik üreten kullanıcılar öncelikle kendi kişisel çıkarları için UGC oluşturmaktadır.

- Bilgi işlevi, insanların çevrelerini organize etmek ve anlamak için bilgi edinme ihtiyacı tarafından yönlendirildiğini kabul eder. Yani, deneyimlerimizi anlama ve anlamlandırma ihtiyacıyla motive olmak üzerinedir. Bu nedenle UGC'nin yaratıcıları; bilgelik duygusu hissettikleri için ve kendilerini anlamalarına yardımcı olduğu için UGC üretmektedirler.

- Değer ifade etme işlevi, insanların öz kavramlarını ve değerlerini ifade etmelerine veya ilişkilendirmelerine izin veren ve ahlaki inançları eşleştirerek dünyanın gözündeki imajını geliştiren tutumları gerektirmektedir. Bu nedenle, UGC'nin yaratıcıları, içerik oluşturdukları ve önemli olduğunu düşündükleri ilkeleri paylaşan çevrimiçi bir topluluğun üyesi oldukları için öz saygı duygusuyla doğaları gereği tatmin olmuş hissederler.

- Ego-savunma işlevi, kişinin kendi imajını savunma iç işlevine hizmet eden, insanları iç güvensizliklerden veya dış tehditlerden korumak için tasarlanmış motivasyonları temsil etmektedir. Ego-savunma işleviyle motive olan UGC yaratıcıları kendi şüphelerini en aza indirmek, aidiyet duygusu hissetmek ve muhtemelen katkıda bulunmama konusundaki suçluluk duygularını azaltmak için UGC oluşturmaktadırlar. 


\section{Araştırmanın amacı ve önemi}

Araştırmada örneklem olarak iletişim fakültesi öğrencilerinin seçilme nedeni, kullanıcı türevli içeriklere ve bunun satın alma davranışına etkisine karşı kavrayışlarının ders içerikleri dolayısıyla yüksek olabileceği düşüncesine dayanmaktadır. İletişim fakültesi öğrencileri tüketici, reklam, e-WOM veya kullanıcı içeriği gibi kavramlara aşina olabileceği, hangi içerik kurumsal, hangisi kullanıcı türevli daha fazla ayırdında olabileceği varsayıldı ̆̆ı için tercih edilmiştir. Ek olarak, üniversite öğrencileri, ekonomik özgürlük sahibi yüksek yaş gruplarına kıyasla tüketici deneyimi az ve teknoloji etkileşimi yüksek olduğu için kullanıı içerikleri ile ilişkileri (içerik üretme ve içeriklerden etkilenme) klişeleşmemiş ve kalıplaşmamış olduğu düşünülerek tercih edilmiştir. Araştırma soruları ise şöyledir:

- Cinsiyet ve çevrimiçi harcanan zaman gibi değişkenler, tüketici içeriğinin etkisinde farklılık yaratır $\mathrm{m}$ ?

- Öğrencilerin tüketici olarak içerik üretme eğilimleri en çok ne tür (olumlu/olumsuz) deneyimlerden etkilenmektedir?

- Öğrenciler en çok hangi alanlardaki kullanıcı içeriklerinden etkilenmektedir?

- Öğrenciler kurumsal mı yoksa tüketicilerin yarattığı gönüllü içeriklere mi daha çok güvenmektedir?

Tüketicilerin hem satın alma öncesi hem de satın alma sonrası kullanıcı içeriklerinden etkilenme düzeyi ve tüketicilerin tüketim deneyimi sonrası içerik üretme eğilimleri incelenmektedir. Ayrıca cinsiyet ile kullanıcı kaynaklı içeriklerin her geçen gün yoğunlaştığı ve ilgi gördügü günümüz dijital dünyasında tüketicilerin deneyimlerinin genç tüketiciler özelinde güncel olarak incelenmesi hem markalar/işletmeler hem de farklı pek çok tüketici açısından değerli görülmesi nedeniyle ve literatüre katkı sağlayacağı düşünülmektedir.

\section{Yöntem}

Araştırmada nitel bir yöntem olan anket/sormaca yöntemi uygulanmıştır. 24/04/2018 tarihli 45 başvuru numaralı etik kurul raporuna göre anket etik açıdan uygun bulunmuştur. Anketler 463 kişiye uygulanmış ve sadece 1 anket temel işlevselliği olan bilgileri boş bırakması sebebiyle veri setinden çıkartılmıştır. Diğer boş bırakılan ifadelerin yer aldığı anketlere ortalama atama yöntemi uygulanarak veri kaybı önlenmiştir. Araştırmacılar, elde ettikleri veriler üzerinde gerçekleştirdikleri analizlerden doğru sonuçlar elde edebilmek için kayıp veriler yerine yaklaşık değer atamaktadırlar. Yaklaşık değer atama yöntemlerinden biri ortalama atama yöntemidir (Çüm ve Gelbal, 2015, s. 89). Deterministik nitelikteki bu yöntem, eksik veri bulunan değişkenin genel aritmetik ortalamasının alınmasını veya duruma göre sınıf içi ortalamasının alınmasını ve bu değerin eksik verilerin yerine yazılmasını ifade etmektedir (Şencan, 2005, s. 217).

\section{Veri toplama araçları}

Anket formu hazırlanması süresince yerli ve yabancı literatür incelemeleri ile gerekli bilgi zemini sağlanmıştır. Soruların hazırlanma sürecinde benzer alanlarda yapılan çalışmalardan yararlanılmıştır. Kullanıcı içeriklerinin faydalılığı ve satın alma niyetine etkisi ile ilgili sorular Mikalef, Giannakos ve Pateli (2013, s. 33-34) ve To, Liao ve Lin (2007, s. 782) satın alma öncesi ve sonrası kullanıcı içeriği ile ilgili sorular İşlek (2012, s. 164-168) kullanıcı içeriklerinin turizm ve seyahat etkileri ile ilgili sorular Cox vd., (2009, s. 760) çalışmalarından araştırmacının amacına ve içeriğine göre uyarlanmıştır. Satın alma öncesi bölümde 20 ifade, satın alma sonrası bölümde 5 ifade bulunmaktadır. Bu ifadelere katılımların ölçülmesinde 5'li Likert tipi ölçek kullanılmıştır. Ankette satın alma öncesi ile ilgili ifadeler genel olarak; kullanıcı içeriklerinin bilgi edinme için gerekliliğini, güvenilirliğini, olumlu ve olumsuz etki düzeyini sormaktadır. Kullanıcı içeriklerinden, kitap ve dergi, film, sinema ve tiyatro, kafe ve restoran, destinasyon ve konaklama yeri, teknolojik ürün gibi tercihler yaparken ne kadar yararlandıkları sorulmaktadır. Ek olarak; kullanıcı içeriklerinin kaynağının kurumsal ise ne kadar güven duyulduğu, gönüllü tüketici içeriği ise ne kadar güven duyulduğu, akran veya arkadaş, ünlü veya popüler kişiler ise ne kadar güven duyulduğu gibi sorular bulunmaktadır. Satın alma sonrası ifadelerde ise; internetteki kullanıcı içeriklerinin satın alma sürecini ne kadar etkilediği sorulmaktadır. Satın alma sonrası diğer ifadeler ise, tüketim deneyiminde memnuniyete ve memnuniyetsizliğe dayanan içerik üretme eğilimini öğrenme amaçlıdır. Son olarak, İnternette bulunma süreleri, hangi 
aygıtla eriştikleri ve kullanıcı içeriklerine erişilen ortamlardan (sosyal medya, blog, forum, vlog) hangisini daha çok kullandıkları sorulmaktadır.

\section{Verilerin analizi ve kullanılan testler}

Öncelikle araştırmada kullanılan ölçeklerdeki her bir ifade için güvenilirlik analizleri yapılmıştır. Sosyal bilimler alanında yapılan çalışmalarda 0.70 Cronbach Alpha katsayısı yeterli görülmektedir, bu anketin Cronbach Alpha katsayısı ise $0,829^{\prime}$ dur. Ölçeklerin normal dağılıma uyup uymadığını değerlendirmek üzere çarpıklık ve basıklık değerleri incelenmiştir. Elde edilen sonuçlara göre; çarpıklık ve basıklık değerinin $+2 /-2$ aralığında yer aldığı ve verilerin normal dağılım sağladığı saptanmıştır. Bunun yanında, örneklem büyüklüğünün yeterliliği sebebiyle ( $\mathrm{N}$ : 462) araştırmada parametrik testlerin kullanılması uygun görülmüştür. Araştırmada hipotez testleri için independent sample $t$ test, paired sample $t$ test, pearson correlation testi ve one way anova testi uygulanmıştır.

\section{Bulgular}

Araştırmanın yaş ve cinsiyet değişkenlerinden elde edilen bulgulara bakıldığında katılımcıların ortalama yaşının 21,15 olduğu görülmektedir. Katılımcıların \%55,2'si (N=255) kadın, \%44,8'i (N=207) erkektir. Araştırmaya katılan bireylere günlük ortalama internet süreleri sorulmuştur. Elde edilen bulgulara göre; günde 1 saatten az internet başında zaman geçirenler toplam katılımcıların \%4,3'ünü (N: 20) oluşturmaktadır. 1-3 saat arası zaman geçirenlerin oranı ise \%21,9 (N: 101), 3-5 saat arası zaman geçirenlerin oranı $\% 36,1(\mathrm{~N}: 167)$ buna karşılık 5 saatten fazla zaman geçirenlerin oranı ise $\% 37,7^{\prime}$ dir (N: 174).

Tablo 1: Katılımcıların İnternette Geçirdikleri Zaman

\begin{tabular}{|l|c|}
\hline Seçenekler & Frekans (Yüzde) \\
\hline 1 saatten az & $20(\% 4,3)$ \\
\hline $1-3$ saat & $101(\% 21,9)$ \\
\hline $3-5$ saat & $167(\% 36,1)$ \\
\hline 5 saatten fazla & $174(\% 37,7)$ \\
\hline
\end{tabular}

Katılımcılara, internet ortamındaki kullanıcı içeriklerinin satın alma süreçlerini ne kadar etkilediği sorulduğunda katılımcıların \%3,7'si (N: 17) hiç etkilemez derken, \%7,8'i (N: 36) etkilemez, \%29,9'u (N: 138) ne etkiler ne etkilemez, \%48,5'i (N: 227) etkiler, buna karşıllk \%10,2'si (N: 47) ise çok etkiler şeklinde yanıt vermiştir. Buna göre katılımcıların, satın alma kararı verirken internetteki kullanıcı içeriklerinden etkilendikleri söylenebilir.

Tablo 2: Kullanıcı İçeriklerinin Satın Alma Kararına etkileri

\begin{tabular}{|l|l|}
\hline Seçenekler & Frekans (Yüzde) \\
\hline Hiç Etkilemez & $17(\% 3,7)$ \\
\hline Etkilemez & $36(\% 7,8)$ \\
\hline Ne Etkiler, Ne Etkilemez & $138(\% 29,9)$ \\
\hline Etkiler & $224(\% 48,5)$ \\
\hline Çok Etkiler & $47(\% 10,2)$ \\
\hline
\end{tabular}

Katılımcıların interneti en sık hangi aygıtlar üzerinden kullandığına yönelik soruya verilen yanıtlar incelendiğinde; interneti en sık akıllı telefon/cep telefonu aracılığıyla en az ise tablet aracılığıyla kullandıkları görülmektedir. 
Tablo 3: İnternet Erişim Aygıtları ve Kullanım Sıklıkları

\begin{tabular}{|c|c|c|c|c|c|c|c|c|}
\hline \multicolumn{2}{|l|}{ Cihazlar } & Hiç & Nadiren & Ara sira & Sik sik & Sürekli & Ortalama & $\begin{array}{l}\text { Standart } \\
\text { Sapma }\end{array}$ \\
\hline Bilgisayar & $\begin{array}{l}\mathrm{N} \\
\%\end{array}$ & $\begin{array}{l}37 \\
8\end{array}$ & $\begin{array}{l}43 \\
9,3\end{array}$ & $\begin{array}{l}113 \\
24,5\end{array}$ & $\begin{array}{l}127 \\
27,5\end{array}$ & $\begin{array}{l}142 \\
30,7\end{array}$ & 3,63 & 1,23 \\
\hline Tablet & $\begin{array}{l}\mathrm{N} \\
\%\end{array}$ & $\begin{array}{l}188 \\
40,7\end{array}$ & $\begin{array}{l}115 \\
24,9\end{array}$ & $\begin{array}{l}91 \\
19,7\end{array}$ & $\begin{array}{l}33 \\
7,1\end{array}$ & $\begin{array}{l}35 \\
7,6\end{array}$ & 2,17 & 1,24 \\
\hline Akıllı Telefon & $\begin{array}{l}\mathrm{N} \\
\%\end{array}$ & $\begin{array}{l}8 \\
1,7\end{array}$ & $\begin{array}{l}4 \\
0,9\end{array}$ & $\begin{array}{l}16 \\
3,5\end{array}$ & $\begin{array}{l}59 \\
12,3\end{array}$ & $\begin{array}{l}375 \\
81,6\end{array}$ & 4,71 & 0,73 \\
\hline
\end{tabular}

Katılımcıların sosyal medya araçlarını kullanma sıklıkları incelendiğinde; en sık kullanılan sosyal medya araçları 4,13 ortala ile sosyal ağlar iken, en az kullanılan sosyal medya aracı ise 1,46 ortalama ile podcasttir. Katılımcılar arasında Facebook, İnstagram, Snapchat, Foursquare vb. sosyal ağları sürekli kullananların oranı \%47,6 iken, sık sık kullananların oranı ise \%31,6'dır. Bu sonuca göre her beş katılımcıdan dördü sosyal ağları sıklıkla kullanmaktadır.

Katılımcıların satın aldıkları ürüne ilişkin içerik üretmelerine yönelik sunulan önermelere verdikleri yanıtlar incelendiğinde; satın alınan ürün veya hizmetlerle ilgili içerik üretme sıklığı 1 ile 5 arasında değerlendirildiğinde ortalama 2,71'dir. Katılımcılar en fazla, satın alınan ürün veya hizmetten memnun kalmadıklarında diğer kullanıcılara almamalarını tavsiye ederim yanıtını vererek 3,65 ortalama oluşturmuşlardır.

İnternet kullanım süresinin, kullanıcı içeriklerinden etkilenme düzeyini etkileyeceği öngörülmektedir. Kadın ve erkeklerin internet kullanımları arasında ise farklılıklar olduğunu ileri süren araştırmalar mevcuttur. Yine Erciyes Üniversitesi öğrencilerinin internet kullanım alışkanlıkları ile ilgili yapılan bir araştırmaya göre erkeklerin interneti daha sık ve daha fazla kullandıkları sonucuna varılmıştır (Koçer, 2012, s. 80-81). İnterneti daha fazla kullanmanın kullanıcı içeriklerinden daha fazla etkilenmeye neden olabileceği çıkarımına dayanarak;

\section{H1: Cinsiyetlere göre kullanıcı içeriklerinden etkilenme düzeyi farklılık gösterebilir.}

Katılımcıların cinsiyetlerine göre kullanıcı içeriklerinden etkilenme düzeyleri arasında istatistiksel olarak anlamlı bir fark olup olmadığını incelemek üzere öncelikle ölçekteki tüm sorulara verilen yanıtların ortalaması alınıp yeni bir değişken oluşturulmuş ardından elde edilen değişkene independent sample $t$ testi uygulanmıştır. Independent Sample $t$ testine göre; kadınların kullanıcı içeriklerinden etkilenme düzeyi 3,49 iken erkeklerin etkilenme düzeyi ise 3,44' tür. Cinsiyet değişkeni anlamlı bir farklılık yaratmamakta ve $\mathrm{H}_{1}$. reddedilmektedir (t: 0,902, p: 0,358).

İnternette geçirilen zaman değişkeni kategorik olarak toplanmıştır. İnternette geçirilen zamana bağlı internetin sunduklarından etkilenmenin farklılaşacağ 1 üzerine oluşturulan hipotez şöyledir;

H2: İnternette harcanan zamana göre katılımciların kullanıcı içeriklerinden etkilenme düzeyi farklılık gösterebilir.

İnternette geçirilen zamana bağlı kullanıcı içeriklerinden etkilenme düzeylerinde fark olup olmadığını incelemek üzere öncelikle ölçekteki tüm sorulara verilen yanıtların ortalaması alınıp yeni bir değişken oluşturulmuş, ardından elde edilen değişkene hem One Way Anova testi uygulanmıştır. Bireylerin internet başında geçirdikleri sürenin kullanıcı içeriklerinden etkilenmeleri üzerinde anlamlı bir etkisi olduğu tespit edilmiştir (F: 5,662, p: 0,001). İnternette geçirilen harcanan zaman arttıkça kullanıcı içeriklerinden etkilenme düzeyi, istatistiksel olarak anlamlı bir artış göstermekte ve $\mathrm{H}_{2}$ desteklenmektedir.

Bireylerin çevrimiçi ortamlarda geçirdikleri zamanın artmasının içerik üretme eğilimlerinde farklılık yaratacağı öngörülerek kurulan hipotez şöyledir;

H3: Internette harcanan zamana göre içerik üretme eğilimi düzeyi farklllık gösterebilir.

Katılımcıların internette harcadıkları zamana bağlı içerik üretme eğilim düzeyleri arasında istatistiksel olarak anlamlı bir fark olup olmadığını incelemek üzere öncelikle ölçekteki tüm sorulara verilen yanıtların ortalaması alınıp yeni bir değişken oluşturulmuştur. Ardından elde edilen değişkene One 
Way Anova testi (F: 1,202, p: 0,302) uygulanmıştır. Yapılan analiz sonucunda; bireylerin internette geçirdikleri sürenin içerik üretme eğilimleri üzerinde istatistiksel olarak anlamlı bir etkisi olmadığı tespit edilmiş ve $\mathrm{H}_{3}$ doğrulanmamıştır.

Olumsuz UGC'nin nötr veya olumlu-olumsuz karışık içeriklere göre satış üzerinde daha fazla etkisi olduğu ve bu etkinin de negatif olduğu ileri sürülmektedir (Tang, Fang ve Wang, 2014, s. 52). Bu bilgi üzerine temellendirilen hipotez şöyle ifade edilmektedir;

$\mathrm{H}_{4}$ : Negatif kullanıcı içerikleri ile negatif tüketici davranışı arasında pozitif bir ilişki vardır.

Negatif kullanıcı içerikleri ile negatif tüketici davranışı arasında pozitif bir korelasyon olup olmadığını incelemek üzere "Olumsuz kullanıc yorumlarından etkilenirim" ve "Satın alacağım ürün veya hizmet hakkında olumsuz yorum ve görüşlere rastlıyorsam satın almam" önermelerine Pearson korelasyon testleri uygulanmıştır. Elde edilen bulgulara göre katılımcların her iki önermeye verdikleri yanıtlar bakımından istatistiksel olarak anlamlı ve pozitif yönlü bir ilişki bulunmakta (r: 0,402 , p: 0,001) ve $\mathrm{H}_{4}$ doğrulanmaktadır.

Olumlu UGC'nin Olumlu UGC'nin nötr veya olumlu-olumsuz karışık içeriklere göre satış üzerinde pozitif etkisi olduğu ileri sürülmektedir (Tang vd. s, 54). Bu bilgiye göre oluşturulan hipotez şöyledir;

H5: Pozitif kullanıcı içerikleri ile pozitif tüketici davranışı arasında pozitif bir ilişki vardır.

Pozitif kullanıcı içerikleri ile pozitif tüketici davranışı arasında pozitif korelasyon olup olmadığını incelemek üzere "Olumlu kullanıcı yorumlarından etkilenirim" ve "Eğer bir ürün/hizmet ile ilgili olumlu yorum ve görüşlerle karşılaşırsam satın almam daha muhtemeldir" önermelerine Pearson korelasyon testleri uygulanmıştır. "Eğer bir ürün/hizmet ile ilgili olumlu yorum ve görü̧slerle karşılaşırsam satın almam daha muhtemeldir" önermesine kesinlikle katılmıorum yanıtını verenlerin \%20" si "Olumlu kullanıcı içeriklerinden etkilenirim" önermesine kesinlikle katılmıyorum yanıtını vermişlerdir. "Ĕğer bir ürün/hizmet ile ilgili olumlu yorum ve görüşlerle karşılaşırsam satın almam daha muhtemeldir" önermesine kesinlikle katılıyorum yanıtını verenlerin \%54,4' ü "olumlu kullanıcı içeriklerinden etkilenirim" önermesine kesinlikle katılıyorum yanıtını vermiştir. Elde edilen bulgulara göre katılımcların her iki önermeye verdikleri yanıtlar bakımından istatistiksel olarak anlamlı ve pozitif yönlü bir ilişki bulunmakta ve (r: 0,402, p: 0,001) bu ilişki $\mathrm{H}_{5}^{\prime}$ i desteklemektedir.

Bazı araştırmalar tüketicilerin diğer tüketici görüşlerini uzman eleştirmenlerin görüşlerinden daha çok benimsediklerini kanıtlamıştır (Smith vd., 2005, s. 32; Dellarocas vd., 2007, s. 39). H6 ise Tüketicilerin, pazarlama profesyonellerinin ve reklamcıların içeriklerine kıyasla, sıradan insanların ürün incelemelerine ve görüşlerine daha fazla güven duyacağı varsayımı üzerine temellendirilmiş ve şöyle ifade edilmiştir:

H6: Kullanıcıların ürettiği içeriğe duyulan güven, kurumsal içeriklere duyulan güvenden daha yüksektir.

Kullanıcıların ürettiği içeriğe duyulan güvenin, kurumsal içeriklere duyulan güvenden daha yüksek olup olmadığını sorgulamak üzere "Satın alacağım ürün/hizmet ile ilgili bilgiler tüketici tarafindan oluşturulmuşsa o bilgiye güvenirim" ve "Satın alacă̆ım ürün/hizmet ile ilgili bilgiler kurum tarafından oluşturulmuşsa o bilgiye güvenirim" önermelerine verilen yanıtlara Paired sample $\mathrm{t}$ test uygulanmıştır. "Satın alacağım ürün/hizmet ile ilgili bilgiler tüketici tarafindan oluşturulmuşsa o bilgiye güveninim." önermesine verilen yanıtların ortalaması 3,33 iken, "Satın alacağım ürün/hizmet ile ilgili bilgiler kurum tarafından oluşturulmuşsa o bilgiye güvenirim." önermesine verilen yanıtların ortalaması ise 3,29' dur. Çok küçük bir farklılık olduğundan dolayı kullanıcıların ürettiği içeriğe duyulan güven ile kurumsal içeriklere duyulan güven arasında istatistiksel olarak anlamlı bir farklılık bulunmamıştır. (t: 0,663, p: $0,508)$ Ancak yapılan başka bir araştırmaya göre tüketicilerin ikna edici etkisi pazarlamacının ikna edici etkisinden 22 kat daha fazladır (Yong Goh vd., 2013, s. 103).

Tüketicinin ürün memnuniyeti sonrasında şirkete yardım etme arzusu oluşmaktadır (Sundaram vd., 1998). Deneyimlerin sevincini başkalarıyla paylaşma arzusundan doğan bu gerginlik pozitif deneyimini ifade ederek serbest bırakılmakta ve böylelikle e-WOM' a katkıda bulunmaktadır (Dichter, 1966'dan akt. Hennig-Thurau vd., 2004, s. 44). Bu bilgilere dayanarak oluşturulan hipotez şöyle ifade edilmektedir. 


\section{H7: Tüketim deneyiminin olumluluğu ile yorum/görüş̧̈̈retme eğilimi arasında pozitif bir ilişki vardır.}

Tüketim deneyiminin olumluluğu ile yorum/görüş üretme eğilimi arasında pozitif korelasyon olup olmadığını incelemek üzere "Satın aldığım ürün/hizmetten memnun kalırsam bununla ilgili yorum ve görüşlerimi internet ortamlarında paylaşırım" ve "Satın aldığım ürün veya hizmetlerle ilgili içerik üretirim." önermelerine ve Pearson korelasyon testleri uygulanmıştır. Elde edilen bulgulara göre istatistiksel olarak anlamlı ve pozitif yönlü bir ilişki bulunmaktadır (r: 0,332, p:0,001). H7 doğrulanmaktadır.

Memnuniyetsizliği paylaşma eğiliminin memnuniyeti paylaşma eğilimine kıyasla daha yüksek olacağ 1 varsayımı üzerinde temellendirilen hipotez şöyle ifade edilmiştir;

\section{Hs: Tüketim deneyiminin olumsuzluğu ile yorum/görüş üretme eğilimi arasında pozitif bir ilişki vardır.}

Tüketim deneyiminin olumsuzluğu ile yorum/görüş üretme eğilimi arasında pozitif korelasyon olup olmadığını incelemek üzere "Satın aldığım ürün/hizmetten memnun kalmazsam bununla ilgili yorum ve görüşlerimi internet ortamlarında paylaşırım" ve "Satın aldığım ürün veya hizmetlerle ilgili içerik üretirim." önermelerine Pearson korelasyon testleri uygulanmıştır. Elde edilen bulgulara göre katılımcıların her iki önermeye verdikleri yanıtlar bakımından istatistiksel olarak anlamlı ve pozitif yönlü bir ilişki bulunmakta (r: 0,278, p: 0,001) $\mathrm{H}_{8}$ desteklenmektedir.

\section{Sonuç, tartışma ve öneriler}

Araştırma sonucunda edinilen bulgulara göre genç tüketicilerin kullanıcı içeriklerinden en çok seyahat planlaması yaparken yararlandıkları görülmüştür. Ayrıca katılımcıların en çok sırasıyla; bir teknoloji ürünü satın alırken, sinema veya film seçerken, kafe, restoran tercihi yaparken, kitap veya dergi seçerken yararlandıkları görülmektedir. Katılımcıların çoğu satın alacakları ürün veya hizmet ile ilgili tanıdıkları kişilerin ve arkadaşlarının tavsiyelerine önem verdiklerini belirtmiştir. Bu bulgu, Smith ve arkadaşlarının akran önerilerine güvenilirliğin yüksek olduğunu ileri süren çalışmasıyla örtüşmektedir (2005, s. 30).

Bir zamanlar sadece yakınlarımıza sormak ile sınırlanan tercih ve satın alımlarımız bugün dijitalleşme ve web 2.0 teknolojileri sayesinde dönüşüm göstermiştir. Bu dönüşüme son zamanlara artan mobilite hız ve güç kazandırmakta, çevrimiçi geçirilen zamanı artırmaktadır. Bu araştırmaya göre, gençlerin interneti en çok akıllı telefon aracılığıyla kullandıkları ve çoğunun günde 5 saatten fazla çevrimiçi zaman geçirdikleri ileri sürülmektedir.

Bulgulara göre gençlerin çevrimiçi ortamda en fazla zaman geçirdikleri alan sosyal ağlardan sonra bir vlog ağı olan Youtube bulunmaktadır. E-Marketer verilerine göre blog, UGC'nin en popüler şeklini oluşturmaktadır (Tomaiuolo, 2012, s. 5). Blogculuğu bu denli güçlü kılan, Web 2.0 'ın sunduğu özellikler sayesinde kolektif zekayı kullanarak, Web'i bir tür küresel beyne dönüştürmesidir (O'Reilly, 2012, s. 26). Bloglar amatör yayıncılı̆ğ geliştirirken (Anderson, 2008, s. 72) özellikle video bloğu anlamına gelen vlogculuğun en popüler örneğini ise Youtube oluşturmaktadır. Kullanıcı türevli video içeriklerinin en popüler hali olan Youtube, televizyon programlarının, filmlerin ve müzik kliplerinin yanı sıra kullanıcıların ürettikleri parodilerle zenginleşmekte, yorum yazma ve mesajlaşma imkanı sunduğu için bağlantıların artmasını sağlamaktadır (Karahasan, 2012, s. 176). Kullanıcı içeriklerinin gelecekte daha da görsel odaklı dönüşüm geçirebileceğini ileri sürmek işten bile değildir.

Bulgulara göre, çevrimiçi geçirilen zaman arttıkça içerik üretme eğiliminin artış göstermeme nedeni; basit bir değerlendirme veya puanlamanın bile zaman ve çaba gerektirmesine bağlanabilir. Tutumu oluşturan motivasyonlar yeterince güçlü değilse eyleme dönüşmeyebilir yani içerik üretme eylemi gerçekleşmeyebilir. Bulgulara göre olumlu kullanıcı içeriklerinin satın almayı kolaylaştırdığı olumsuzların ise satın almayı zorlaştırdığı ileri sürülebilir. Olumsuz UGC'nin nötr veya olumluolumsuz karışık içeriklere göre satış üzerinde daha fazla negatif etkisi olduğu (Tang vd., 2014, s. 52) olumlu UGC'nin nötr veya olumlu-olumsuz karışı içeriklere göre satış üzerinde pozitif etkisi olduğunu ileri süren çalışma ile de örtüşmektedir (Tang vd., 2014, s. 54).

Bulgular, tüketicilerin kurumsal içeriklere mi yoksa kullanıcı içeriklerine mi daha fazla güvendikleri konusunda küçük bir fark dolayısıyla anlamlı bir farklılık olmadığını göstermektedir. Bu bulgu, kullanıcı içeriklerinin pazarlama içeriklerine göre ikna edici etkisinin 22 kat daha fazla (Yong Goh vd., 2013, s. 103) oluğunu ileri süren çalışmaların aksinedir. Buna neden olan ihtimaller olarak; 
katılımcıların, UGC'yi oldukça popüler olan influencer/etki pazarlaması ile karıştırmış olabilecekleri düşünülmektedir. Diğer bir ihtimal ise katılımcıların iletişim fakültesi öğrencileri olması, gelecekte firmalar için içerik yaratan kişiler olma potansiyelleri nedeniyle kendilerini güvenilir görme gibi doğal bir eğilim sonucu bulgulanmış olabilir. İletişim fakültesi öğrencileri alan bilgisi ve mesleki eğilimleri nedeniyle, güven konusunda kurumsal içeriklere ve UGC' ye aynı mesafede kalabilir.

Tüketicilerin satın alma sonrası içerik üretme eğilimleri incelendiğinde, katılımcıların en fazla memnun kalmadıklarında içerik ürettikleri bulgulanmıştır. Bu tıpkı bir yabancıyla iletişime geçerken genellikle bir olumsuzluk hakkına konuşmaya başlamanın daha kolay olması klişesini akla getirmektedir.

Kadınların UGC'lere güvenme eğiliminin daha yüksek olduğu bulgusunu veren araştırmaların aksine (Lim, Lim, K. ve Heinrichs, 2014) bu araştırmada kullanıcı içeriklerinden etkilenme düzeyinde cinsiyet farklılığı saptanmamıştır. Ancak kullanıcı içeriğini yaratan kaynağın, cinsiyet değiş̧kenine göre daha güvenilir algılanıp algılanmadığı gelecekte araştırmaya değer bir konu olabilir. Bu konuda Amerika'da yapılan bir çalışma, içeriklerin kadınlar tarafından oluşturulduğunda daha güvenilir algılandığı ihtimalini araştırmış ve anlamlı bir farklılık saptamamıştır (Sethna, Hazari ve Bergiel, 2017). Ülkemizde de güven konusunda kullanıcı içeriğinin kaynağının cinsiyet değişkenine göre değişkenlik gösterip göstermediği araştırılabilir. Kullanıcı içeriklerinin satın alma ve tercihlerimiz üzerinde önemli bir etkisi vardır bu nedenle firmalar kullanıcılara kendi haklarında olumlu bir şeyler üretmeleri için nedenler vermelidir. Turizmden kültür sanat aktivitelerine, restoranlardan, nesnel tüketim ürünlerine kadar kullanıcıların içerik üretmeleri teşvik edilebilir. Genel itibariyle kullanıcı türevli içeriklerin etkilerinin hem tüketiciler açısından hem de işletmeler/markalar açısından önem taşıması nedeniyle araştırmaların çeşitlendirilmesi önerilmektedir. Gelecek araştırmalar, farklı örneklem gruplarına farklı sorularla güncellenebilir. Yine benzer olarak farklı örneklemlerle yapılmış araştırmalar birbirleriyle karşılaştırılarak derinleştirilebilir. Ayrıca kullanıcı yorum ve tavsiyelerinin doğruluğu ile ilgili araştırmaların yapılması kullanıcı içerikleri konusunda daha derin bir kavrayış sağlayabilir.

\section{Hakem Değerlendirmesi / Peer-review:}

Dış bağımsız

Externally peer-reviewed

\section{Çıkar Çatışması / Conflict of interests:}

Yazar(lar) çıkar çatışması bildirmemiştir.

The author(s) has (have) no conflict of interest to declare.

\section{Finansal Destek / Grant Support:}

Yazar bu çalışma için finansal destek almadığını beyan etmiştir.

The author declared that this study has received no financial support.

\section{Etik Kurul Onayı / Ethics Committee Approval:}

$\mathrm{Bu}$ çalışma için etik kurul onayı, Erciyes Üniversitesi, Sosyal ve Beşerî Bilimler Etik Kurulu/Komitesinden 24/04/2018 tarihli 45 sayılı karar ile alınmıştır.

Ethics committee approval was received for this study from Erciyes University, social and humanities Ethics Committee on 24/04/2018, 45 document number. 


\section{Yazar Katkıları / Author Contributions:}

Fikir/Kavram/Tasarım- Idea/Concept/ Design: T.B Veri Toplama ve/veya İşleme- Data Collection and/or Processing: T.B. Analiz ve/veya Yorum- Analysis and/or Interpretation: T.B. Kaynak Taramas1- Literature Review: T.B., Makalenin Yazımı- Writing the Article: T.B., Eleştirel İnceleme- Critical Review: E.T.M, Onay- Approval: E.T.M

\section{Kaynakça / References}

Ahuja, R.D., Anne Michels, T., Mazzei Walker, M. \& Weissbuch, M. (2007), Teen perceptions of disclosure in buzz marketing, Journal of Consumer Marketing, 24(3), 151-159. https://doi.org/10.1108/07363760710746157

Anderson, C. (2008). Uzun Kuyruk-Geleceğin İşi: Çoğun Azını Satmak, İstanbul: Optimist Yayınları.

Bagozzi, R. P., \& Dholakia, U. M. (2002). Intentional social action in virtual communities. Journal of Interactive Marketing, 16(2), 2-21. https:/doi.org/10.1002/dir.10006

Bansal, H. S., \& Voyer, P. A. (2000). Word-of-Mouth Processes Within a Services Purchase Decision Context. Journal of Service Research, 3(2), 166-177.

Chatterjee, P. (2001). Online Reviews: Do Consumers Use Them? Association for Consumer Research, $18(2), 129-134$.

Cox, C., Burgess, S., Sellitto, C., \& Buultjens, J. (2009). The role of user-generated content in tourists' travel planning behavior. Journal of Hospitality and Leisure Marketing, 18(8), 743-764. https://doi.org/10.1080/19368620903235753

Çüm, S., \& Gelbal, S. (2015). Kayıp Veriler Yerine Yaklaşık Değer Atamada Kullanılan Farklı Yöntemlerin Model Veri Uyumu Üzerindeki Etkisi. Mehmet Akif Ersoy Üniversitesi Eğitim Fakültesi Dergisi, 35, 87-111.

Daugherty, T., Eastin, M. S., \& Bright, L. (2008). Exploring Consumer Motivations for Creating UserGenerated Content. Journal of Interactive Advertising, 8(2), 16-25. https://doi.org/10.1080/15252019.2008.10722139

Dellarocas, C., Zhang, X. M., \& Awad, N. F. (2007). Exploring The Value Of Online Product Reviews in Forecasting Sales: The Case of Motion Pictures. Journal of Interactive Marketing, 21(3), 2-20. https://doi.org/10.1002/dir

Dhar, V., \& Chang, E. A. (2009). Does Chatter Matter? The Impact of User-Generated Content on Music Sales. Journal of Interactive Marketing, 23(4), 300-307. https://doi.org/10.1016/j.intmar.2009.07.004

Gretzel, U. (2006). Consumer Generated Content -Trends and Implications for Branding. E-Review of Tourism Research, 4(3), 9-11.

Handley, A., \& Chapmen, C. C. (2012). Dijital Çağda İçerik Yönetiminin Kuralları, İstanbul: Mediacat Yayıncilik.

Hennig-Thurau, T., Gwinner, K. P., Walsh, G., \& Gremler, D. D. (2004). Electronic word-of-mouth via consumer-opinion platforms: What motivates consumers to articulate themselves on the Internet? Journal of Interactive Marketing, 18(1), 38-52. https://doi.org/10.1002/dir.10073

Hermida, B. A., \& Thurman, N. (2007). Comments please : How the British news media are struggling with user-generated content. 8th International Symposium on Online Journalism Austin University of Texas Online, 2009(April 3), 1-28.

https://soundcloud.com/

https://tiyatrolar.com.tr/

https://www.imdb.com/

https://www.tripadvisor.com.tr/\# 
https://www.bizevdeyokuz.com/

https://www.goodreads.com/

İşlek, M. (2012). Sosyal Medyanın Tüketici Davranışlarına Etkileri: Türkiye'deki Sosyal Medya Kullanıcıları Üzerine Bir Araştırma, Karamanoğlu Mehmetbey Üniversitesi Sosyal Bilimler Enstitüsü, Yüksek Lisans Tezi, Karaman.

Jeong, E. H., \& Jang, S. C. S. (2011). Restaurant experiences triggering positive electronic word-of-mouth (eWOM) motivations. International Journal of Hospitality Management, 30(2), 356-366. https://doi.org/10.1016/j.ijhm.2010.08.005

Karahasan, F. (2012). Taşlar Yerinden Oynarken Dijital Pazarlamanın Kuralları, İstanbul: Doğan Kitap Yayınları.

Karkar, A. (2016). Değer ve Güven Ağlarının Yükselişinde İçerik Pazarlaması Content Marketing on the Increase of Value and Confidence Network. 2(1).

Katz, D. (1960). American Association for Public Opinion Research The Functional Approach to the Study of Attitudes Authors ( s ): Daniel Katz Source: The Public Opinion Quarterly, Vol . 24 , No . 2 , Special Issue: Attitude Change Published by: Oxford University Pres. The Public Opinion Quarterly, 24(2), 163-204.

Koçer, M. (2012). Erciyes Üniversitesi Öğrencilerinin İnternet ve Sosyal Medya Kullanım Alışkanlıkları. Akdeniz Üniversitesi İletişim Fakültesi Dergisi, 18, 70-86.

Krumm, J., Davies, N., \& Narayanaswami, C. (2008). User Generated Content. Environmental Science and Technology, 7(4), 10-11. https://doi.org/10.1021/es0725605

Lim, J., Lim, K., \& Heinrichs, J. H. (2014). Gender and mobile access method differences of Millennials in social media evaluation and usage: An empirical test. Marketing Management Journal, 24(2), 124135.

Liu, Y. (2006). Word of mouth for movies: Its dynamics and impact on box office revenue. Journal of Marketing, 70(3), 74-89. https://doi.org/10.1509/jmkg.70.3.74

Mikalef, P., Giannakos, M., \& Pateli, A. (2013). Shopping and word-of-mouth intentions on social media. Journal of Theoretical and Applied Electronic Commerce Research, 8(1), 17-34. https://doi.org/10.4067/S0718-18762013000100003

Namkung, Y., \& Jang, S. C. (2007). Does Food Quality Really Matter in Restaurants? Its Impact On Customer Satisfaction and Behavioral Intentions. Journal of Hospitality and Tourism Research, 31(3), 387-409. https://doi.org/10.1177/1096348007299924

O'Connor, P. (2008). User-Generated Content and Travel: A Case Study on Tripadvisor.Com. Information and Communication Technologies in Tourism 2008, 47-58. https://doi.org/10.1007/9783-211-77280-5_5

O'Reilly, T. (2012). What is web 2.0?: Design patterns and business models for the next generation of software. The Social Media Reader, 65, 32-52.

Şencan, H. (2005). Sosyal ve Davranışsal Ölçümlerde Güvenilirlik ve Geçerlilik, Ankara: Seçkin Yayıncilik.

Sethna, B. N., Hazari, S., \& Bergiel, B. (2017). Influence of user generated content in online shopping : impact of gender on purchase behaviour, trust, and intention to purchase. Int. J. Electronic Marketing and Retailing, 8(4), 344-371.

Smith, D., Menon, S., \& Sivakumar, K. (2005). Online peer and editorial recommendations, trust, and choice in virtual markets. Journal of Interactive Marketing, 19(3), 15-37. https://doi.org/10.1002/dir.20041

Sundaram, D. S., Mitra, K., \& Webster, C. (1998). Word-of-mouth communications: A motivational analysis. Advances in Consumer Research, 25, 527-531.

Tang, T. Y., Fang, E. E., \& Wang, F. (2014). Is Neutral Really Neutral ? The Effects of Neutral User- 
Generated Content on Product Sales. Journal of Marketing, 78, 41-58. https://doi.org/10.1509/jm.13.0301

Thi, N., Thao, T., Shurong, T., \& Distric, B. (2020). Is It Possible for “ Electronic Word-of-Mouth " and " User-Generated Content " to be Used Interchangeably? Journal of Marketing and Consumer Research, 65, 41-48. https://doi.org/10.7176/JMCR/65-04

Tiago, T., Amaral, F., \& Tiago, F. (2015). The Good, the Bad and the Ugly: Food Quality in UGC. Procedia - Social and Behavioral Sciences, 175, 162-169. https://doi.org/10.1016/j.sbspro.2015.01.1187

To, P. L., Liao, C., \& Lin, T. H. (2007). Shopping motivations on Internet: A study based on utilitarian and hedonic value. Technovation, 27(12), 774-787. https://doi.org/10.1016/j.technovation.2007.01.001

Tomaiuolo, N. G. (2012). UContent: The Information Professional's Guide to User-generated Content. Information Today, Incorporated. ProQuest Ebook Central. Created from gazi-ebooks on.

Toros, D. N. (2016). Pazarlama İletişimi Açısından İnternet Ortamında Kullanılan Ağızdan Ağıza Pazarlama Tekniklerinin Marka Tercihine Etkisi. Üsküdar Üniversitesi Sosyal Bilimler Dergisi, 1, $157-182$.

Vickery, G., \& Vincet, S. W. (2007). Participative Web And User-Created Content: Web 2.0 Wikis and Social Networking. Organization for Economic Cooperation and Development (OECD).

Yong Goh, K., Heng, C.-S., \& Lin, Z. (2013). Social Media Brand Community and Consumer Behavior: Quantifying the Relative Impact of User- and Marketer-Generated. 24(1), 88-107. 